\title{
Immigrant Communities, the Police and the Courts in Late Eighteenth and Early Nineteenth-Century London
}

Peter King

\section{(2) OpenEdition \\ Journals}

Electronic version

URL: http://journals.openedition.org/chs/1639

DOI: $10.4000 /$ chs.1639

ISSN: 1663-4837

Publisher

Librairie Droz

\section{Printed version}

Date of publication: 1 June 2016

ISBN: 978-2-600-01953-8

ISSN: 1422-0857

\section{Electronic reference}

Peter King, «Immigrant Communities, the Police and the Courts in Late Eighteenth and Early

Nineteenth-Century London », Crime, Histoire \& Sociétés / Crime, History \& Societies [Online], Vol. 20, n

1 | 2016, Online since 01 June 2018, connection on 19 April 2019. URL : http://

journals.openedition.org/chs/1639; DOI : 10.4000/chs.1639

\section{This text was automatically generated on 19 April 2019}

(c) Droz 


\title{
Immigrant Communities, the Police and the Courts in Late Eighteenth and Early Nineteenth-Century London ${ }^{1}$
}

\author{
Peter King
}

1 Although research on the late nineteenth and twentieth centuries has indicated the vital role that ethnicity and migrant status played - and continues to play - in determining the ways the accused were treated by the police and the courts, until recently very little work has been done on the late eighteenth century and the early years of the nineteenth ${ }^{2}$. General monographs on the Jewish community and on the black presence in the eighteenth century have sometimes included chapters on crime and justice ${ }^{3}$, but they have been hampered by their reliance on two sources that never consistently recorded the ethnicity of the accused : the Old Bailey Sessions Papers (henceforward OBSP) and the crime reports frequently found in London's many newspapers. Nor have any of these overviews made use of a micro-history approach, individual cases being frequently mentioned but never followed through in detail. This article aims to deepen our understanding of the treatment of migrant groups within the criminal justice system both by presenting a detailed micro-history of one important but neglected case for which particularly full documentation has survived, and by exploiting a unique set of records, the Newgate Calendars, which (unlike the OBSP and the newspapers) record the ethnicity of all the accused for a brief period between 1791 and 1805. (Here 'Newgate Calendars' refers to the criminal registers of offenders awaiting trial at the Old Bailey in Newgate Prison rather than the popular accounts of crimes and executions published under a similar title) ${ }^{4}$.

2 This research centres on London not only because the capital generated a uniquely detailed set of court records in which ethnicity is systematically described, but also because its huge population of nearly one million in 1800 contained large numbers of migrants. These came not only from other parts of England and from the other three 
nations which made up the United Kingdom after 1801 - Ireland, Scotland and Wales but also from Europe and beyond $\mathrm{d}^{5}$. The first half of the article uses a case-study approach based on a detailed micro-history of one specific and well-documented old Bailey case which involved a highly contentious accusation of murder that ended in several of the accused being sent to the gallows. This case highlights the ways both the London police and those who ran the capital's courts sometimes followed patterns of behaviour that were deeply discriminatory. It is difficult not to conclude from this prosecution that embedded in policing policies, in the role played by the London magistracy, in old Bailey trial procedures and in the judge's instructions to the jury, was a specific and deliberate attempt to victimise a group of accused taken from London's largest migrant group, the Irish. This then raises the broader question addressed in the second half of this article: How typical was this discriminatory behaviour? This is investigated through a quantitative study of nearly 12,000 cases for which the information is much less deep, but for which trustworthy information on the ethnicity and/or place of birth of the accused is available, making statistical comparisons between the London-born accused and those from various migrant backgrounds possible for the first time.

The core questions that will be addressed through these intersecting, but very different, methodologies will be the same: Did the main decision-making groups in the criminal justice process - the police and the key actors in the courts (i.e. prosecutors, lawyers, grand jurors, petty jurors and judges) - treat ethnic/immigrant minorities in much the same way as they treated all offenders, or were some or all of these migrant groups treated very differently when they were accused of crimes at the Old Bailey? Along with John Carter Wood, the author of this article has recently published two highly focussed studies of the ways members of the Irish and black communities were treated when they came to the courts as victims, prosecutors, witnesses, watchmen, or offenders ${ }^{6}$. The approach taken in this article is more focussed, not only because it is partly based on a micro-history, but also because it looks only at how migrant groups were treated when they came to the Old Bailey as the accused, rather than as victims or witnesses. In one important sense, however, this article presents a much broader picture than any of the work so far published because it analyses all the main migrant groups among the old Bailey accused. It also discusses not only their treatment by the courts, but the different types of offence they committed and their occupational and lifecycle characteristics, rather than focussing - as previous writings have done - almost solely on the Jewish, black and Irish accused ${ }^{7}$.

\section{I}

4 The starting point of this study is a micro-history of one 1799 old Bailey homicide case. This produced the longest trial recorded in the eighteenth century which ran to more than 60 pages of the printed OBSP as well as being very widely reported in the press ${ }^{8}$. It has, however, almost entirely escaped the notice of historians. It is a marvellous story in itself, but it is also a fascinating window into the nature of police strategies in late eighteenth-century London, into police attitudes towards ethnic minorities, into the ways the courts backed up the police, even when their activities were illegal, and into the consequences of being from the wrong migrant/ethnic group at the wrong time in late eighteenth-century England. 
The story began in St Giles - one of the poorest parishes in London, where many of the capital's Irish population (30,000 to 40,000 in all) lived in the late eighteenth century9. It centred initially on the Kings Arms, in Maynard Street, a "very narrow, dirty street" with virtually no lighting. Events began to unfold between nine and ten at night on Boxing Day (26 December), "a day", to quote counsel for the defence, "upon which the lower sort of Irish always meet for the purposes of merriment"10. There are minor points of disagreement in the surviving accounts about the precise sequence of events. Broadly speaking, however, a clear common story emerges from the trial evidence and the newspaper reports, although the ways different actors chose to interpret the legal meanings of these events was a source of considerable conflict.

6 That evening, the 26 December 1798, a crowd of labouring men were sitting downstairs in the tap room of the King's Arms drinking and smoking. The Irish landlord, Thomas Flannery, was, by his own account, enjoying a quiet glass of rum and water in the parlour of his pub with two friends : John Harris, an undertaker, and one Quin, a market man. He could observe the bar from where he was and all was quiet and peaceable ${ }^{11}$. Upstairs between thirty and forty men and women, who were regular members of an Irish Cock and Hen club, were singing, dancing and enjoying the music of a fiddle player, having paid six pence each for the pleasure of spending their Boxing Day evening in this way. Eleanor Hern was sitting at the head of the table as 'Female President' of the Club ${ }^{12}$. Mary Regan, a young woman who sold fruit to the club, was plying her trade ${ }^{13}$. No riot or disorderly conduct was taking place.

7 At this point a very large contingent of policemen - Bow Street patrols and local constables from various London parishes ( 50 was the most common estimate but one paper reported 58 in all $)^{14}$ - burst into the King's Arms unannounced. They presented a warrant permitting them to arrest any vagrants or idle and disorderly persons that were present. They were under verbal instructions, it appears, to arrest any deserters they found, since Sir William Addington, the Chief Magistrate at Bow Street, believed that "a great number of deserters" ${ }^{\prime 15}$ resorted there. Armed with truncheons, and in many cases with cutlasses already drawn, they rushed upstairs. They then broke up the club, arrested both the male and female participants and, after handcuffing them together, began removing them to the local watch-house - taking the landlord and his friends into custody as well, without giving any specific reason why they were doing so. However, as the police tried to remove the Irish men and women they had arrested they were assaulted first by one or two Irishmen and soon by a growing crowd of them. Some of the officers remained in the King's Arms while most of them battled their way to the local watch-house attempting to prevent the rescue of their prisoners. In the meantime John Sullivan, an Irish chairman employed by the Marchioness of Donegal, who was one of those originally arrested but had by this time got out of custody, had run to another pub a hundred yards away, The Ship in Bainbridge Street. Here he successfully recruited reinforcements declaring "What do you stand there for and see people cut to pieces" ${ }^{16}$. As a result the officers who remained at the King's Arms soon found themselves attacked by an even larger group of armed Irishmen and they were now quite severely outnumbered, because most of their original party were no longer there but involved in the process of taking those they had arrested back to the Watch-house. Shouting anti-English slogans such as "halloo for the bloody Sassanacks" 17 and conversing largely in Irish, the crowd counterattacked in force with bludgeons and cutlasses laying into the remaining patrol officers. A major riot ensued and after a bloody battle in the tap room and in the street 
several officers were badly wounded and a Bow Street Patrol Captain, Duncan Grant, was so severely injured that he died a few weeks later ${ }^{18}$.

8 In reporting Grant's death and the subsequent Coroner's hearing, the London press focussed almost solely on the role of the Irish as instigators of the riot and as the main perpetrators of the violence. "A numerous Banditti of Irish armed with bludgeons, cutlasses etc... wounded several of the officers very severely" The Sun and several other newspapers reported ${ }^{19}$, whilst neglecting to mention that many of the police had entered the pub with cutlasses already drawn and had been equally free in using them to severely wound many of those who resisted arrest ${ }^{20}$. The role played by the police in initiating the conflict was also ignored in these reports. The London Chronicle, for example, described the riot as "made by a number of Irishmen in St Giles"21. By the beginning of March intense activity by various Bow Street officers had led to the arrest of more than a dozen suspects, including one who had nearly escaped by entering himself as a landsman aboard an East-Indiaman ${ }^{22}$. By this time feelings were clearly running high amongst the Irish community. Several papers reported that when the suspects where brought from the House of Correction at Cold Bath Fields to the preliminary hearing on the 30th March (after which they were committed to Newgate to await trial) "the Magistrates sent for a party of the guards to escort them" in order "to prevent any rescue being attempted" 23 .

At the ensuing old Bailey trial, eight Irishmen and two Irish women were indicted for Duncan Grant's murder. The cases against the women, one of whom was Eleanor Hern, the 'chairwoman' of the Cock and Hen club, were dropped at the beginning of the proceedings $^{24}$ - raising questions about why they have been held in gaol for nearly five months awaiting trial. The case against four of the men also proved problematic and halfway through the trial the prosecution agreed that they too should be found not guilty 25. At this point the case against the remaining four also looked extremely dubious, mainly because the warrant turned out to have been illegal. Legally two magistrates had to meet, have a hearing and then sign the warrant. In reality Addington had got a fellow magistrate to sign a pile of draft warrants and leave them on hand for him to use whenever he felt like it. The warrant did not therefore arise from a legal hearing, which requires the presence of two magistrates ${ }^{26}$. Given that the arrests were therefore anything but legal, the defence lawyers argued cogently that assaulting the police in order to prevent such an arrest is not against the law and that a whole range of past cases provided solid case-law precedents to the effect that an unpremeditated homicide occurring in these circumstances could only be indicted as manslaughter and could never amount to murder ${ }^{27}$. In an era of very short trials, this trial was one of the longest the old Bailey had ever known, "the whole of the day from morning until nine o'clock at night"28 being taken up by it. The lengthy legal arguments largely went the defence's way - even the judge himself admitted grudgingly under duress that the warrants were of very dubious legality ${ }^{29}$. Given the long line of legal precedents in their favour, the defendants had every hope of getting off with a manslaughter conviction at the very worst.

However, the forces ranged against the four remaining accused - Timothy Brian, John Sullivan, Patrick Holland and Cornelius Donohough - were considerable. The offence was represented by counsel for the prosecution as "of the highest importance to the police of the country" ${ }^{\prime 3}$. The government therefore set about orchestrating the case against the rioters, employing as attorney for the prosecution a man who also worked as a clerk at the Bow Street Police Office - a decision which the defence counsel unsuccessfully challenged at a preliminary hearing. ${ }^{31}$ Although evidence had been produced that made it 
clear that there was no 'disorderly conduct' going on in the King's Arms until the police arrived, (the undertaker, for example, observed that it was the officers who began the riot by rushing violently into the house with cutlasses drawn) ${ }^{32}$, and although no adequate explanation was ever given as to why at least 50 police officers were sent to a place where no crime was being committed and about which no complaint had been received, a police officer had suffered multiple wounds and other officers had had arms and other limbs broken or slashed. The much-vaunted fairness of the English courts - a subject of lengthy discussion in many eighteenth-century pamphlets ${ }^{33}$ - was about to be tested.

11 It magnificently failed this test. The judge constantly took the prosecution's side. Having been forced to admit that the warrant was illegal he got round the inevitable consequence of this admission - that the non-capital offence of manslaughter was the maximum charge that the accused could be convicted of - by arguing that the arrests had already been completed by the time the fatal attack took place. The murder was therefore not a consequence of a rescue mounted to release those illegally arrested but the product of a malicious, revengeful and premeditated counter-attack by the Irish mob ${ }^{34}$. This alternative narrative was not without purchase, but those who wished to prioritise this way of portraying the facts faced many problems since some of those arrested were still being held by the police in the King's Arms when the fatal attack took place. The defence produced persuasive evidence that a considerable number of women, and at least one man, were still under arrest in a separate room in the building at this point ${ }^{35}$, but in his summing up the judge completely ignored this part of the evidence. Acting directly in contradiction to contemporary legal theory, which argued that the judge's summing up should be factual and neutral, Judge Grose used this opportunity to directly attack and undermine every point that had been made by the defence in the accused's favour. Even the defendants' character witnesses, of which there were many, were criticised and undermined by the bench, and although, in his final summing up, he did allow that the jury could find that the murder occurred during a rescue attempt, he made it clear that "it cannot be contended, it seems to me, that it was done in prosecution of such an attempt." ${ }^{36} \mathrm{He}$ then went on to solemnly remind the jury to "remember how material it is in this great town that the peace should be preserved ... if you recollect that, and then attend to the evidence ... that these men had a pernicious, premeditated plan, of doing mischief to the officers, then your duty to the public calls on you to say they are guilty of murder not manslaughter ... I am firmly persuaded that when you lay your heads together your verdict will be formed upon good sense and justice and that, with that verdict, the public will be perfectly satisfied." ${ }^{37}$ The jury may or may not have been affected by this clear lead from the judge but after retiring for half an hour - a very long period of jury deliberation by the standards of the eighteenth century - they eventually returned a verdict of guilty on three of the four accused. Only Donohough, the case against whom - as the judge pointed out in his summary - rested on fewer witnesses, was acquitted. ${ }^{38}$

12 The other three were convicted of murder and immediately sentenced to be hanged and then to have their bodies delivered to the surgeons "to be anatomised and for exposition" ${ }^{39} \mathrm{in}$ accordance with the requirements of the 1752 Murder $\mathrm{Act}^{40}$. They were hanged the following Monday at 8 O'clock in the morning outside Newgate, "attended by a Popish Priest" with whom they were said to have spent "about a quarter of an hour in fervent prayer." "The concourse of people which attended on this melancholy occasion", the 
True Briton recorded, "was astonishingly great" ${ }^{42}$ and the crowd was almost certainly sympathetic, since The Star reported that "their fate was very much pitied" by the "great concourse of people that attended." ${ }^{43}$ Their bodies were then put in a cart and conveyed to a house in Castle Street, Clerkenwell, for dissection ${ }^{44}$. The English state had quite literally torn them apart. Although much was made of the 'mercy' shown to the other seven accused, in reality this trial was about terror not mercy. The hanging of these three Irishmen - despite the fact that their counsel had clearly presented an extremely strong counter-case, based on both the facts and the case law, which indicated that they could only fairly be found guilty of manslaughter - suggests strongly that this was a clear example of judicial prejudice.

\section{II}

13 This case also raises a number of questions about the role of the police in late eighteenthcentury metropolitan life. As Ruth Paley and a number of other historians have shown, the pre-1829 London police were by no means the wretched and inadequate force that those who advocated police reform made them out to be ${ }^{45}$. Indeed by the final years of the eighteenth century Bow Street had become the centre of an ever widening network of police patrols as well as of a considerable number of effective detective agents ${ }^{46}$. Following the 1792 Act, Police Offices with stipendiary magistrates, each of whom had command of a group of paid constables, had been established in every part of London apart from the City ${ }^{47}$. These stipendiary magistrates now had the capacity to be proactive in their policing strategies and this was particularly true of Addington, who as head of what was acknowledged to be the chief police office of the metropolis - and much the best funded ${ }^{48}$ - could bring together a large strike force by combining Bow Street Patrolmen and local constables, as he did before the Cock and Hen club attack. Although we now have an excellent detailed history of the other smaller force under Addington's command - the Bow Street Runners -as well as of the of the night watch ${ }^{49}$ historians have yet to investigate in any depth the impact of the coming of the Bow Street Patrol on patterns of policing in the Metropolis. By the 1790s an armed patrol of around 70 men was based at Bow Street, but apart from brief references to their role in watching the main roads into London relatively little has been written about their activities or about the power their existence gave to the head of the Bow Street Office to initiate large scale police searches and other proactive policing ventures ${ }^{50}$.

We know that in the troubled decade of the 1790s the London police not infrequently arrested members of radical or insurrectionary groups which the authorities either suspected of sedition or simply wished to suppress ${ }^{51}$ - groups that would have included both Londoners and immigrants. In 1797, for example, Addington organised a raid on a London Corresponding Society Meeting, and in January 1798 he used the patrole to arrest "a number of Frenchmen and other foreigners" accused of holding a seditious gathering. ${ }^{52}$ However, it remains unclear whether places where specific immigrant groups tended to gather were raided simply because of the ethnicity or nationality of those who gathered there. Nor do we have any systematic source that has left a record of such raids. The archives of the Bow Street Office have not survived and since it is likely that routine raids would only have been reported in the London newspapers if a policeman had been badly hurt or killed, or if the raid had proved particularly newsworthy for some other reason, we will probably never know just how frequently the police used these tactics. The 
activities of the police on Boxing Day 1798 came to the attention of the public primarily because a policeman was killed and an old Bailey murder trial was mounted, but how many other similar raids did the police mount without their activities being recorded or publicised because no major casualties resulted? Without any systematic records it is not possible to ascertain how regularly the police targeted the Irish, or other immigrant groups. However, we do have access to some fragmentary evidence that other fairly similar raids took place in the late 1780s and 1790s, because preliminary hearings before the Bow Street magistrates were sometimes reported in this period, and offenders who had injured officers during affrays arising from other police raids were sometimes brought to that court.

In 1789, for example, a "desperate affray" occurred in a house of ill fame in Turnmill Street, Clerkenwell, when the magistrates, having heard that a regular weekly club attended by bullock-hunters, thieves and prostitutes met in the house ordered "a number of officers to apprehend them as disorderly persons." ${ }^{53}$ As in the 1798 raid, however, the officers were attacked by members of the club wielding pokers, bludgeons, shovels and other weapons and several of the constables were "dangerously hurt" ${ }^{24}$ including the High Constable of the Finsbury division whose life was thought to be "in great danger" 55 and who eventually died a few years later from the long term effects of the cuts to the head, breast and shoulders he received that night ${ }^{56}$. The disturbance was eventually quelled and seven of the offenders arrested and imprisoned, but only after "the assistance of the watch and the patrole was... procured and the windows of the attic story were entered by the officers. ${ }^{17}$ If the available newspaper reports are any guide Bow Street officers did not regularly suffer fatal or near fatal injuries in such raids, but a search of all the available newspaper reports for 1797 and 1798 has revealed one other similar raid involving a near fatal clash between the Irish and the Bow Street Patrole.

In May 1797 a considerable number of newspapers carried reports of a police raid on another Irish pub in St Giles, the Golden Hart, in which at least two members of the patrole received wounds so serious that the surgeon called in to dress them considered "their lives in danger." ${ }^{58} \mathrm{~A}$ variety of reports of the incident appeared in the London newspapers, but although there were many minor differences of detail and although some reports were more explicit than others about the precise reasons for the raid, the outlines of the story was very similar in each. "In consequence of an information received at the Public Office Bow Street, that a number of the lower class of Irish, supposed to hold a correspondence with their brethren (the Defenders) in Ireland, had seditious meetings at the Golden Hart public house" 59 , a small party of police, were "dispatched to the house" with a search warrant in order to apprehend them. "It not being expected many would be found, only one constable and about eight of the patrole" were sent. On arrival, however, they found a "large assembly" of between 60 and a 100 Irish men and women ${ }^{60}$ gathered for "what is termed a Cock and Hen Club, of which the landlady of the house was president." ${ }^{11}$ When the patrole attempted to secure the male members of the club, the Irish (both the men and the women) "after a short conversation in their own language, rushed upon the patrole and threw some of them downstairs, took from them their staffs and cutlasses", and "wounded six of them in a very shocking manner." ${ }^{62}$ The officers escaped in disarray - one had to jump out of a first story window - and it is clear that the raid was an abject failure. "Not one of the villains was taken" ${ }^{63}$ and although the landlord and landlady of the Golden Hart were arrested and temporarily held in custody, they 
"refused to discover any of the persons that were present" when brought before the Bow Street Court ${ }^{64}$.

The failure of the 1797 raid and the injuries sustained by Addington's officers may help to explain why he chose to put together such a huge force on Boxing Day 1798, but the events of May 1797 also suggest both that the attitudes the police displayed towards the Irish on Boxing Day 1798 had a longer history and that they were based in part at least on the authorities' very specific antagonism towards the Irish generated by the broader military situation. Addington's raids on the Irish community in St Giles in the later 1790s do not necessarily indicate a deep long-term prejudice against the Irish. These initiatives could have been a much more temporary phenomenon created by growing fears of a rebellion in Ireland, at a time when the British state was at war with France and anxieties about the threat posed by the French - and about the likelihood that Irish would form an alliance with England's traditional enemy - were particularly acute. When the Rebellion actually came in 1798 , led by the United Irishmen and by the Defenders, with whom they were in league ${ }^{65}$, the alliance the rebels forged with the French rang huge alarm bells in England. Having raged across much of Ireland for several months, the insurrection had only finally ended in October 1798, ten weeks before the Boxing Day raid. Thus while it is clear is that the 1797 and 1798 Cock and Hen Club raids and the tactics the police adopted during them, were highly discriminatory, it is much less clear whether this reflected deeply-held long-term prejudices or merely the specific political and military context, in particular the fears aroused by the United Irishmen and their links to English radical movements. Equally, the 1798 case and the 1799 trial that it led to, cannot automatically be seen as an indication that minority groups were regularly being discriminated against by the courts or the old Bailey judges throughout the late eighteenth and early nineteenth centuries. 1798 and 1799 witnessed the climax of the political repression of Pitt's administration ${ }^{66}$ and Judge Grose's clear desire to ensure that some of the Irishmen accused of the murder of a prominent police officer on Boxing Day 1798 were hanged may have been partly or even mainly caused by this specific political context.

Moreover, any attempt to argue from the1799 trial, that English judges were generally prejudiced towards the Irish immediately strikes another major methodological problem. Killing a police officer - let alone a Bow Street patrole captain - was particularly likely to bring down the wrath of the authorities upon the perpetrator, whatever his or her ethnic background. Lacking exactly parallel cases involving similar murders of police officers in similar circumstances by non-Irish - and preferably English - perpetrators, it is therefore very difficult to draw any broader conclusions, although the detailed reconstruction which Drew Gray and Peter King have recently published of the hanging of a young English man for the alleged murder of a Northamptonshire village constable provides an interesting, if not a precise, parallel. Though the accused in this 1789 case was defending his elderly father from a riotous, violent and potentially lethal attack by local villagers, which meant that there was a very strong case for reducing his offence to manslaughter, he too had to go to the gallows, although in this case local sympathy for his cause led to a long petitioning campaign and prevented his body being handed over for dissection ${ }^{67}$.

Clearly therefore, while individual micro-histories offer a unique opportunity to study the depth of prejudice which the judicial system and the policing agencies could show towards particular minorities, we need to go beyond this approach if we want to analyse the degree to which different ethnic and immigrant groups experienced systematic longterm prejudice and negative discrimination in the courts. This is precisely what the 
Newgate Calendars of the period 1791-1805, enable us to do. These records systematically record place of birth, ethnicity, crime, verdict and punishment, as well as other useful characteristics of the accused such as their age and occupation. This makes it possible to analyse what proportion of the accused came from various ethnic/national groups, what backgrounds those groups came from, and what impact place of birth/ethnicity had on the fate of the old Bailey accused both when it came to deciding their guilt or innocence, and then - if they were found guilty - when decisions were made about what punishment they should be given.

\section{III}

For a brief period from 1791 until 1805 the Newgate Calendars described those accused of crimes at the Old Bailey in much greater detail than they had previously done or would subsequently do. In October 1800 , for example John Simmonds was described as follows : 'Age 23, $5 \mathrm{ft} 7$ in, fair complexion, dark brown hair, hazel eyes, born in St Giles (London), a shoemaker.' For the first 10 years any perceived racial characteristics were also recorded. John Robinson was described in the same sessions as 'Age 23, 5ft 8in, a negro, woolly hair, black eyes, born in Kingston, Jamaica, a sailor. ${ }^{98}$ This offers historians of crime two potential ways of analysing the impact of ethnicity. Systematic information on place of birth enables us to look at the treatment of migrant groups such Irish, German or Scottish offenders while the relatively small number of black accused who were specifically labelled as such (and the even smaller number of Jews so labelled) provide a similar opportunity. Unfortunately this is only possible for the major crimes tried at the old Bailey. There are no equivalent systematic records about those appearing for lesser, and always non-capital, offences before the quarter sessions, city sessions or summary courts. It cannot therefore be assumed that the patterns found here were also replicated in these lower courts. However, since on average over a thousand offenders came up for trial every year at the Old Bailey, nearly 12,000 offenders are available to study between 1791 and 1805 , despite the fact that three of the yearly Newgate Calendar volumes have not survived.

The extent to which different ethnic/national groups were over- or under-represented among the 1791-1805 accused is very difficult to calculate, given that we have no precise figures before the mid-nineteenth century census on the proportion of London's population that came from Ireland, Scotland, etc. - and no census counts at all of black or Jewish people. However, we can make some reasonably accurate guesses and these suggest that while the majority of migrant communities were considerably overrepresented among those indicted at the Old Bailey, others were not. As Table 1 indicates, more than three fifths of the Old Bailey accused were born outside London. Most of these (42.3 percent of the total sample) came from - or at least were born in - the rest of England. The South-Eastern Counties around London tended to contribute the largest numbers, but even the far western county of Cornwall was significantly represented, contributing an average of 5 accused per year. The rest of the non-metropolitan-born accused (17.9 percent in all) came from outside England. 14.5 percent were born in the rest of the United Kingdom, while 2.0 percent came from Europe and 1.4 percent from the rest of the world. Patrick Colquhoun's complaint in 1797 that 'London is not only the grand magazine of the British Empire, but also the general receptacle for the idle and depraved of almost every country, and certainly from every quarter of the dominions of 
the Crown' ${ }^{69}$ does get some support from the wide range of countries that the accused were born in. Between 1791 and 1805 the Old Bailey tried offenders from all over the nonEuropean world - from Barbados, Barbary, Bengal, and Boston, from Calcutta, St Christopher, Charlestown and Cape Francis. An average of over 8 American and 3 West Indian accused stood trial every year, (Jamaica alone supplying at least one), while the East Indies, and Africa (broadly defined to include Madeira) each contributed on average just under one offender a year. ${ }^{70}$

Table 1 - Old Bailey Accused, 1791-1805 : Place of Birth

\begin{tabular}{|l|l|l|}
\hline Place of Birth & No accused & \% Accused \\
\hline London & 4544 & 39,9 \\
\hline Rest of England & 4763 & 41,8 \\
\hline Cornish & 56 & 0,5 \\
\hline Ireland & 1188 & 10,4 \\
\hline Scotland & 269 & 2,4 \\
\hline Wales & 189 & 1,7 \\
\hline Germany & 101 & 0,9 \\
\hline Rest of Europe & 121 & 1,1 \\
\hline Rest of the World & 157 & 1,4 \\
\hline Total known & 11388 & 100,0 \\
\hline Unknown & 539 & 4,5 \\
\hline Total Sample & 11927 & 100,0 \\
\hline
\end{tabular}

TNA, HO26 1-11. cover Oct 1791-Dec 1805. Oct 1795-Sept 1796 \& Oct 1798-Sept 1800 missing ; Dec 1794-Sept 1795 contain no ethnic data.

22 A wide range European countries also contributed to the Old Bailey accused. On average the Newgate Calendars included around twenty European offenders a year, compared to just over fourteen from the Non-European world. The various provinces that were later labelled as Germany contributed nearly half of these. Around nine per year on average came from this area, which experienced large-scale out-migration in the eighteenth century and also formed London's largest continental grouping throughout this period. ${ }^{71}$ At least one offender every year came from France, Holland, Sweden and Portugal, and even relatively far-flung countries such as Russia, Italy, Greece, Hungary and Poland also made contributions. However, since only 3.4 percent of the Old Bailey accused between 1791 and 1805 came from outside the United Kingdom, the proportion of offenders from Europe and the non-European world hardly bears out either Colquhoun's more general view of London as plagued by offenders from "every country" or the comments made by 
the World newspaper in the early 1790s about the Newgate Calendar teeming "with the names of foreign offenders". ${ }^{72}$

At first glance it may seem surprising that the majority of the Old Bailey accused had not been born in the capital, given that around three fifths of London's population (if the 1851 figures are any guide) were London-born. However, it is important to remember that migrant groups tended to be over-represented among the accused for one very obvious but easily neglected reason. Since the vast majority of migrants did not arrive in the capital until their late teens, twenties or early thirties, the one third of London's inhabitants that was effectively immune from prosecution because they were under 15 had almost all been born in the metropolis. As Table 2 indicates this tendency for the London-born to be more dominant in the capital's younger age groups was very starkly reflected in the age structure of those coming before the Old Bailey, where over a third of the London-born accused were aged twenty or under compared to only a seventh of those born outside the metropolis. Given the much larger proportion of the London-born that were effectively immune from prosecution because very few offenders under fifteen, and virtually none under ten, were ever brought to the court, we would expect immigrants to be rather better represented among the old Bailey accused than they were amongst the London population as a whole and this is broadly true. However, on closer investigation the relationship between ethnicity/nationality and prosecution levels was much more complex.

Table 2 - Old Bailey Accused 1791-1805 : Percentages in each Age Grouping by Place of Birth/ Ethnicity

\begin{tabular}{|l|l|l|l|l|l|l|l|l|l|l|l|l|}
\hline & \multicolumn{1}{|l}{ PLACE OF BIRTH } \\
\hline AGE & All & London & $\begin{array}{l}\text { Rest } \\
\text { of }\end{array}$ & Ireland & Scotland & Wales & Germany & $\begin{array}{l}\text { Rest } \\
\text { of } \\
\text { Eur. }\end{array}$ & $\begin{array}{l}\text { Rest } \\
\text { of } \\
\text { World }\end{array}$ & Unknown & Black & Jewish \\
\hline 7 to 15 & 4,6 & 8,6 & 2,0 & 2,3 & 0,4 & 1,6 & 0,0 & 0,0 & 1,3 & 7,3 & 0,0 & 7,3 \\
\hline 16 to 20 & 17,7 & 27,0 & 12,4 & 9,2 & 7,6 & 12,7 & 6,0 & 7,6 & 14,3 & 16,4 & 11,5 & 9,8 \\
\hline 21 to 25 & 21,9 & 24,1 & 20,5 & 20,5 & 18,6 & 17,5 & 18,0 & 16,9 & 28,6 & 20,9 & 36,5 & 14,6 \\
\hline 26 to 30 & 19,3 & 16,0 & 21,4 & 22,3 & 22,0 & 17,5 & 11,0 & 21,2 & 29,2 & 17,5 & 32,7 & 31,7 \\
\hline 31 to 40 & 21,0 & 15,6 & 24,0 & 26,6 & 30,7 & 27,0 & 30,0 & 18,6 & 16,9 & 18,1 & 15,4 & 12,2 \\
\hline 41 to 50 & 9,0 & 5,2 & 11,5 & 10,3 & 11,4 & 13,2 & 17,0 & 18,6 & 5,2 & 14,1 & 3,8 & 7,3 \\
\hline 51 to 60 & 4,5 & 2,6 & 5,6 & 5,6 & 6,4 & 6,9 & 11,0 & 12,7 & 2,6 & 5,1 & 0,0 & 7,3 \\
\hline 61 to 70 & 1,7 & 0,8 & 2,2 & 2,5 & 2,3 & 2,1 & 7,0 & 3,4 & 0,0 & 0,0 & 0,0 & 4,9 \\
\hline $7 \quad 1 \quad$ or & 0,3 & 0,2 & 0,2 & 0,6 & 0,8 & 1,6 & 0,0 & 0,8 & 1,9 & 0,6 & 0,0 & 4,9 \\
\hline over & 100 & 100 & 100 & 100 & 100 & 100 & 100 & 100 & 100 & 100 & 100 & 100 \\
\hline
\end{tabular}




\begin{tabular}{|l|l|l|l|l|l|l|l|l|l|l|l|l|}
\hline $\begin{array}{l}\text { Age } \\
\text { Known }\end{array}$ & 11486 & 4513 & 4788 & 1183 & 264 & 189 & 100 & 118 & 154 & 177 & 52 & 41 \\
\hline $\begin{array}{l}\text { Age Un } \\
\text { known }\end{array}$ & 441 & 31 & 31 & 5 & 5 & & 1 & 3 & 3 & 362 & \\
\hline $\begin{array}{l}\text { Total } \\
\text { Sample }\end{array}$ & $\begin{array}{l}11 \\
927\end{array}$ & 4544 & $\begin{array}{l}4 \\
819\end{array}$ & 1188 & 269 & 189 & 101 & 121 & 157 & 539 & $52^{*}$ & $43^{*}$ \\
\hline
\end{tabular}

* These offenders double counted because also tabulated under place of birth some further black and jewish offenders included after OBSP identification as such

Migrants from other parts of Britain were the main groups that tended to be overrepresented amongst the accused. In most cases the difference was not particularly great, given the impact of the earlier age profile of the London-born discussed above. The Scots, who constituted around 1.4 percent of the London population in 1841 (and are unlikely to have been a much higher proportion fifty years earlier ${ }^{73}$ accounted for 2.4 percent of the accused. The Welsh-born, who were 0.8 percent of the London population in 1841 and possibly around 1.0 percent in $1800,{ }^{74}$ made up 1.7 percent of the offenders brought to the old Bailey 1791-1805. As I have discussed in detail elsewhere, the only ethnic group that made a greatly disproportionate impact were the Irish. 10.4 percent of the accused were Irish-born but they probably constituted only between 2.0 and 3.0 percent of London's inhabitants 1791-1805, making them between 3.5 and 5.2 times better represented amongst the accused than they were in the general population. ${ }^{75}$ Although we have no figures on the number of Europeans or Non-Europeans living in London in the late eighteenth century, we do have some estimates for the capital's long-established German community which constituted just over 0.42 percent of the London population in 1851 and probably between 0.6 and 0.7 percent in the eighteenth century ${ }^{76}$. Since 0.9 percent of the Old Bailey accused 1791-1805 were German-born this would have meant that, like the Welsh and Scots, they were somewhat over-represented, but not unduly so, given their relative absence in the youngest age groups of the metropolis.

Black offenders, by contrast, were probably under-represented. Although the size of London's black population is the subject of considerable debate amongst historians, in the later 1790s they constituted at least 0.4 percent of the London population and possibly as much as 1.1 percent. Since only 0.4 percent of the accused listed in the Newgate Calendars 1791-1805 were identified as black, their representation amongst those tried at the old Bailey was lower than, or at the most equal to, their representation in the capital's population. ${ }^{77}$ Unfortunately inconsistencies in the Newgate Calendars make it is particularly difficult to gauge whether the Jewish population was under or overrepresented amongst the accused. Between 1791 and 1800 the Registers label only sixteen offenders as Jewish but after this date they are no longer recorded in any way and even for the period 1791-1800 they are clearly under-recorded since a further seventeen accused can be traced as Jewish through the OBSP. However, even if those labelled as Jewish in the criminal registers 1791-1800 represented only a third of the actual Jewish accused, the latter would still have constituted only about 0.6 percent of old Bailey defendants and since Wendeborn's 1791 estimate suggests that between 1.1 and 1.2 percent of the London population were Jewish this would indicate that, like the black population, they were probably under-represented among the accused. ${ }^{78}$ Thus, while 
overall immigrants undoubtedly formed a higher proportion of the accused than they did of the London population in general, there were exceptions to this rule and only one immigrant group - the Irish - made a large and highly disproportionate contribution to the London accused in this period.

As might be expected, the age structure of these different subgroups among the accused (Table 2) partly reflected their migration histories. The proportion of London-born offenders who were teenagers was three times higher than the proportion of Irish accused, and four to five times greater than that found amongst the Scottish or Europeans. Offenders from the non-European world, and especially the one third of the Non-European born who were black, were mainly in their twenties. More than two thirds of the black accused were aged between twenty-one and thirty while only two fifths of the accused in general fell into that category. (Table 2). The percentages in the older age groups followed a very different pattern. German offenders and those from other parts of Europe contained twice the average percentage of over fourty-year olds. Only 3.6 percent of London offenders were over fifty, compared to 17 or 18 percent of the European and of the Jewish accused - the similarity of these two figures being unsurprising since a third of the Jewish accused were European-born.

This older age profile partly reflected the much larger proportion of Jewish and European offenders who were retailers, dealers or merchants - occupations that were much less often followed by the young. (Table 3). Two-thirds of Jewish offenders were shopkeepers, merchants or dealers compared to just 7 percent of all offenders, reflecting the very strong Jewish involvement in certain retail trades. ${ }^{79}$ Unsurprisingly, many Europeans offenders were seamen, as were the majority of those born outside Britain and continental Europe. Non-European offenders were six times more likely to be seamen than the English-born and half of all the Black offenders for whom we have occupational information got their living from the sea. As would be expected from the work of Myers and others on the economic experience of London's black population, the remainder of the black accused were either labourers or servants. ${ }^{80}$ None were recorded as retailers or members of skilled or semi-skilled trades, although more than half of all the Old Bailey accused, and 95 percent of Jewish offenders, fell into these categories. The Scottish and Welsh offenders contained slightly below average numbers in these relatively prosperous retailing and artisan trades, and were both overrepresented amongst the soldiers, while the Welsh (but not the Scots) also had an above average proportion of labourers. The other ethnic group that was considerably under-represented among retailers and skilled artisans and greatly over-represented among the poorest occupations were the Irish accused. Just over half were labelled as labourers, unskilled workers, servants or soldiers, whereas only a third of all accused and 28 percent of the London-born fell into these categories. This data on offenders' occupations therefore follows a fairly similar pattern to that which we would expect from the limited previous research available on the occupations of different ethnic/national groups in late eighteenth-century London. ${ }^{81}$

Table 3 - Percentage of Male Old Bailey Accused in Occupational groups by Ethnicity/Place of Birth 1791-1805

\begin{tabular}{|l|l|l|l|l|l|l|l|l|l|l|l|l|}
\hline $\begin{array}{l}\text { All } \\
\text { Areas }\end{array}$ & London & $\begin{array}{l}\text { Rest } \\
\text { of } \\
\text { Eng. }\end{array}$ & Scotland & Ireland & Wales & Germany & $\begin{array}{l}\text { Rest } \\
\text { of } \\
\text { Eur. }\end{array}$ & $\begin{array}{l}\text { Rest } \\
\text { of } \\
\text { World }\end{array}$ & unknown & Black & Jewish \\
\hline
\end{tabular}




\begin{tabular}{|c|c|c|c|c|c|c|c|c|c|c|c|c|}
\hline $\begin{array}{l}\text { Gentlemen } \\
\text { \&Professional }\end{array}$ & 2,1 & 1,8 & 1,9 & 3,4 & 3,1 & 0,0 & 2,0 & 3,4 & 3,3 & 7,0 & 0,0 & 0,0 \\
\hline $\begin{array}{l}\text { Retailers, } \\
\text { Dealers, } \\
\text { Merchants }\end{array}$ & 7,1 & 6,8 & 7,2 & 10,3 & 2,9 & 12,5 & 26,0 & 13,8 & 3,3 & 8,1 & 0,0 & 66,7 \\
\hline $\begin{array}{l}\text { Farmers and } \\
\text { Husbandmen }\end{array}$ & 0,7 & 0,5 & 1,1 & 0,0 & 0,0 & 0,0 & 0,0 & 0,0 & 0,0 & 1,2 & 0,0 & 0,0 \\
\hline $\begin{array}{l}\text { Skilled/Semi- } \\
\text { skilled trades }\end{array}$ & 34,1 & 40,3 & 33,7 & 17,2 & 21,6 & 27,8 & 20,0 & 17,2 & 5,0 & 33,7 & 0,0 & 9,5 \\
\hline $\begin{array}{l}\text { Semi-skilled } \\
\text { Clothing } \\
\text { trades }\end{array}$ & 11,4 & 13,8 & 9,7 & 15,5 & 10,0 & 8,3 & 8,0 & 10,3 & 6,7 & 8,1 & 0,0 & 19,0 \\
\hline $\begin{array}{l}\text { Sailors, } \\
\text { Seamen } \\
\text { Watermen }\end{array}$ & 10,0 & 8,2 & 8,4 & 21,6 & 12,0 & 6,9 & 16,0 & 31,0 & 53,3 & 19,8 & 48,1 & 0,0 \\
\hline Soldiers & 3,6 & 0,5 & 5,6 & 12,9 & 5,6 & 8,3 & 4,0 & 0,0 & 1,7 & 3,5 & 0,0 & 0,0 \\
\hline $\begin{array}{l}\text { Labourers\& } \\
\text { Unskilled } \\
\text { workers }\end{array}$ & 28,1 & 25,7 & 28,9 & 16,4 & 42,8 & 34,7 & 20,0 & 19,0 & 15,0 & 17,4 & 22,2 & 4,8 \\
\hline Servants & 2,8 & 2,3 & 3,3 & 2,6 & 2,0 & 1,4 & 4,0 & 5,2 & 11,7 & 1,2 & 29,6 & 0,0 \\
\hline Others & 0,1 & 0,1 & 0,2 & 0,0 & 0,0 & 0,0 & 0,0 & 0,0 & 0,0 & 0,0 & 0,0 & 0,0 \\
\hline Total \% & 100 & 100 & 100 & 100 & 100 & 100 & 100 & 100 & 100 & 100 & 100 & 100 \\
\hline Sample size & 4983 & 1986 & 2106 & 116 & 449 & 72 & 50 & 58 & 60 & 86 & $27^{*}$ & $21^{*}$ \\
\hline
\end{tabular}

*These offenders double counted because also tabulated under place of birth some further black and jewish offenders included after OBSP identification as such

The analysis in Table 4 of the impact of ethnicity/nationality on the types of crimes indicted at the Old Bailey 1791-1805 must be approached with care. If similar data on the many routine assaults and minor thefts that came before London's lower courts was available, the picture might be slightly different. However, a large number of minor thefts were tried at the old Bailey and variations in the types of crime that different ethnic groups were indicted for are therefore worth analysing. Overall, it appears that ethnicity/ nationality had a relatively small impact on the types of crime different groups were accused of (Table 4a). About half of the offenders in every ethnic/national category were indicted for simple, non-capital larceny, and about a fifth for shoplifting or pickpocketing. A rather larger proportion of those accused of burglary/housebreaking were London born, (Table $4 \mathrm{~b}$ ) while by contrast relatively few Welsh or Scottish offenders were tried for this offence, but this mainly reflected the fact that younger offenders were the main perpetrators of these crimes and the London accused contained three to four 
times as many teenagers as those born in Wales or Scotland. Apart from housebreaking, the Scottish and Welsh accused followed fairly similar patterns to the sample as a whole across almost all categories of offending, the only other exception being stealing from the dwelling house which the Welsh (and to a lesser extent the Scots) were more prone to be accused of because many of them were living-in servants ${ }^{82}$.

Table 4 - Percentages of Each Crime by Place of Birth, Old Bailey Accused 1791-1805

a. Simplified Version, Six Main Categories of Crime

\begin{tabular}{|c|c|c|c|c|c|c|c|c|c|c|c|c|}
\hline & PLACE & & & & & & & & & & ETHN & ICITY \\
\hline $\begin{array}{l}\text { CRIME } \\
\text { CATEGORY }\end{array}$ & All & London & \begin{tabular}{|l|} 
Rest \\
of \\
Eng.
\end{tabular} & Scotland & Ireland & Wales & Germany & $\begin{array}{l}\text { Rest } \\
\text { of } \\
\text { Eur. }\end{array}$ & $\begin{array}{l}\text { Rest } \\
\text { of } \\
\text { World }\end{array}$ & unknown & Black & Jew \\
\hline $\begin{array}{l}0 . \\
\text { Unknown }\end{array}$ & 1,3 & 0,9 & 1,4 & 0,7 & 0,4 & 0,5 & 1,0 & 0,0 & 0,6 & 7,6 & 0,0 & 0,0 \\
\hline $\begin{array}{l}\text { 1. Plain } \\
\text { Stealing }\end{array}$ & 52,4 & 53,0 & 54,5 & 52,4 & 49,4 & 55,6 & 50,5 & 50,4 & 54,8 & 33,8 & 51,9 & 37,2 \\
\hline $\begin{array}{l}\text { 2. Stealing } \\
\text { Capitally } \\
\text { no } \\
\text { violence to } \\
\text { Person or } \\
\text { Property }\end{array}$ & 19,8 & 22,1 & 19,0 & 18,2 & 18,8 & 21,7 & 20,8 & 19,0 & 18,5 & 10,8 & 26,9 & 20,9 \\
\hline $\begin{array}{l}3 . \\
\text { Housebrea- } \\
\text { king and } \\
\text { Robbery }\end{array}$ & 9,7 & 12,3 & 8,7 & 6,7 & 8,5 & 2,6 & 8,9 & 5,0 & 11,5 & 4,8 & 11,5 & 14,0 \\
\hline $\begin{array}{l}\text { 4. Indirect } \\
\text { Appro- } \\
\text { priation }\end{array}$ & 8,2 & 6,6 & 8,6 & 8,6 & 10,5 & 8,5 & 12,9 & 9,9 & 7,6 & 12,8 & 1,9 & 25,6 \\
\hline $\begin{array}{l}\text { 5. Violent } \\
\text { Crime }\end{array}$ & 3,7 & 2,9 & 3,1 & 4,8 & 7,2 & 4,2 & 2,0 & 5,0 & 3,8 & 6,5 & 5,8 & 0,0 \\
\hline $\begin{array}{l}\text { 6. Other } \\
\text { Crimes and } \\
\text { Misdemea- } \\
\text { nours }\end{array}$ & 4,8 & 2,3 & 4,7 & 8,6 & 5,1 & 6,9 & 4,0 & 10,7 & 3,2 & 23,7 & 1,9 & 2,3 \\
\hline All Crime & 100 & 100 & 100 & 100 & 100 & 100 & 100 & 100 & 100 & 100 & 100 & 100 \\
\hline $\begin{array}{l}\text { Sample } \\
\text { size }\end{array}$ & 11927 & 4544 & 4819 & 269 & 1188 & 189 & 101 & 121 & 157 & 539 & 52 & 43 \\
\hline
\end{tabular}


b. All Categories of Crime

\begin{tabular}{|c|c|c|c|c|c|c|c|c|c|c|c|c|}
\hline & PLAC & & & & & & & & & & ETHN & CITY \\
\hline CRIME & All & London & $\begin{array}{l}\text { Rest } \\
\text { of } \\
\text { Eng. }\end{array}$ & Scotland & Ireland & Wales & Germany & $\begin{array}{l}\text { Rest } \\
\text { of } \\
\text { Eur. }\end{array}$ & $\begin{array}{l}\text { Rest } \\
\text { of } \\
\text { World }\end{array}$ & unknown & Black & Jew \\
\hline $\begin{array}{l}\text { Offence } \\
\text { unknown }\end{array}$ & 1,3 & 0,9 & 1,4 & 0,7 & 0,4 & 0,5 & 1,0 & 0,0 & 0,6 & 7,6 & 0,0 & 0,0 \\
\hline $\begin{array}{l}\text { Stealing / } \\
\text { plain } \\
\text { larceny, }\end{array}$ & 52,4 & 53,0 & 54,5 & 52,4 & 49,4 & 55,6 & 50,5 & 50,4 & 54,8 & 33,8 & 51,9 & 37,2 \\
\hline $\begin{array}{l}\text { Stealing } \\
\text { privately } \\
\text { (from } \\
\text { person or } \\
\text { shop) }\end{array}$ & 9,0 & 12,1 & 6,8 & 5,6 & 8,8 & 7,4 & 5,9 & 9,9 & 8,9 & 6,5 & 9,6 & 7,0 \\
\hline $\begin{array}{l}\text { Stealing } \\
\text { from } \\
\text { dwelling } \\
\text { house }\end{array}$ & 9,2 & 8,7 & 9,9 & 11,9 & 9,4 & 14,3 & 14,9 & 9,1 & 9,6 & 3,2 & 17,3 & 14,0 \\
\hline $\begin{array}{ll}\text { Cow } & \text { or } \\
\text { sheep } & \\
\text { stealing } & \end{array}$ & 0,5 & 0,6 & 0,6 & 0,0 & 0,3 & 0,0 & 0,0 & 0,0 & 0,0 & 0,2 & 0,0 & 0,0 \\
\hline $\begin{array}{l}\text { Horse } \\
\text { stealing }\end{array}$ & 1,0 & 0,7 & 1,7 & 0,7 & 0,2 & 0,0 & 0,0 & 0,0 & 0,0 & 0,9 & 0,0 & 0,0 \\
\hline $\begin{array}{l}\text { Burglary, } \\
\text { house- } \\
\text { breaking }\end{array}$ & 4,8 & 6,6 & 4,2 & 2,2 & 3,1 & 1,1 & 5,0 & 1,7 & 5,1 & 1,7 & 1,9 & 4,7 \\
\hline $\begin{array}{l}\text { Highway } \\
\text { robbery } \\
\text { robbery, }\end{array}$ & 5,0 & 5,7 & 4,5 & 4,5 & 5,4 & 1,6 & 4,0 & 3,3 & 6,4 & 3,2 & 9,6 & 9,3 \\
\hline Receiving & 2,9 & 2,2 & 3,0 & 2,6 & 2,2 & 3,2 & 4,0 & 2,5 & 1,9 & 8,5 & 0,0 & 7,0 \\
\hline $\begin{array}{l}\text { Coining, } \\
\text { uttering etc }\end{array}$ & 1,7 & 1,4 & 1,4 & 0,0 & 4,7 & 0,5 & 4,0 & 3,3 & 1,3 & 0,4 & 0,0 & 14,0 \\
\hline $\begin{array}{l}\text { Indirect } \\
\text { appro- } \\
\text { priation } \\
\text { forgery, } \\
\text { fraud, etc }\end{array}$ & 3,7 & 3,0 & 4,2 & 5,9 & 3,6 & 4,8 & 5,0 & 4,1 & 4,5 & 3,9 & 1,9 & 4,7 \\
\hline
\end{tabular}




\begin{tabular}{|c|c|c|c|c|c|c|c|c|c|c|c|c|}
\hline $\begin{array}{l}\text { Murder/ } \\
\text { Mans- } \\
\text { laughter }\end{array}$ & 1,0 & 0,8 & 0,9 & 1,5 & 1,3 & 1,1 & 1,0 & 0,8 & 1,3 & 2,0 & 3,8 & 0,0 \\
\hline Infanticide & 0,1 & 0,1 & 0,2 & 0,0 & 0,1 & 0,0 & 0,0 & 0,0 & 0,0 & 0,0 & 0,0 & 0,0 \\
\hline $\begin{array}{l}\text { Assaults } \\
\text { nonlethal, }\end{array}$ & 1,6 & 1,5 & 1,4 & 3,0 & 1,9 & 2,1 & 1,0 & 2,5 & 1,9 & 3,0 & 0,0 & 0,0 \\
\hline $\begin{array}{l}\text { Riot and } \\
\text { affray ; }\end{array}$ & 0,6 & 0,3 & 0,4 & 0,0 & 3,1 & 0,0 & 0,0 & 0,8 & 0,0 & 0,7 & 0,0 & 0,0 \\
\hline $\begin{array}{l}\text { Rape (and } \\
\text { attempted } \\
\text { rape) }\end{array}$ & 0,3 & 0,2 & 0,2 & 0,4 & 0,8 & 1,1 & 0,0 & 0,8 & 0,6 & 0,7 & 1,9 & 0,0 \\
\hline $\begin{array}{l}\text { Sodomy/ } \\
\text { Buggery , } \\
\text { bestiality, }\end{array}$ & 0,2 & 0,1 & 0,4 & 0,4 & 0,0 & 0,0 & 0,0 & 0,8 & 0,0 & 0,6 & 0,0 & 0,0 \\
\hline Bigamy & 0,4 & 0,1 & 0,6 & 0,7 & 0,3 & 0,5 & 0,0 & 0,0 & 0,6 & 1,5 & 0,0 & 0,0 \\
\hline $\begin{array}{l}\text { Damaging } \\
\text { property, } \\
\text { arson }\end{array}$ & 0,1 & 0,1 & 0,1 & 0,0 & 0,0 & 0,0 & 1,0 & 0,0 & 0,0 & 0,6 & 0,0 & 2,3 \\
\hline $\begin{array}{l}\text { Combina- } \\
\text { tions by } \\
\text { Workers/ } \\
\text { Strikes }\end{array}$ & 0,2 & 0,0 & 0,3 & 1,9 & 0,3 & 0,5 & 1,0 & 0,0 & 0,0 & 0,0 & 0,0 & 0,0 \\
\hline $\begin{array}{l}\text { Obstructing } \\
\text { assaulting } \\
\text { Excisemen, }\end{array}$ & 0,2 & 0,0 & 0,2 & 0,0 & 0,1 & 0,0 & 0,0 & 0,0 & 0,6 & 2,4 & 1,9 & 0,0 \\
\hline $\begin{array}{l}\text { Perjury/ } \\
\text { and or } \\
\text { Conspiracy }\end{array}$ & 0,6 & 0,2 & 0,5 & 0,7 & 0,6 & 2,6 & 0,0 & 0,0 & 1,3 & 5,4 & 0,0 & 0,0 \\
\hline $\begin{array}{l}\text { Other } \\
\text { Non- } \\
\text { Capital Offs } \\
\text { Misdem }\end{array}$ & 1,9 & 1,0 & 1,8 & 3,0 & 1,4 & 2,6 & 1,0 & 5,8 & 0,0 & 9,8 & 0,0 & 0,0 \\
\hline $\begin{array}{l}\text { Other } \\
\text { Capital Offs } \\
\text { Ret from } \\
\text { trans }\end{array}$ & 1,1 & 0,7 & 1,0 & 1,9 & 2,4 & 0,5 & 1,0 & 4,1 & 0,6 & 3,5 & 0,0 & 0,0 \\
\hline All & 100 & 100 & 100 & 100 & 100 & 100 & 100 & 100 & 100 & 100 & 100 & 100 \\
\hline
\end{tabular}


31 crime and indirect appropriation. The Irish were the only group that was heavily overrepresented amongst the relatively small number of violent offenders that came before the Old Bailey. In total the proportion of Irish offenders accused of murder, assault, riot or rape was twice that of the accused as a whole (Table 4a). Those involved in indirect forms of appropriation also tended to come from particular ethnic groups. Receiving, coining, forgery and fraud constituted only about a twelfth of all indicted crime but more than an eighth of German-born offenders and a quarter of Jewish ones were accused of these crimes. Not surprisingly, given their retailing backgrounds, the Jewish accused were more likely than any other group to be indicted for receiving and were also relatively over-represented amongst those accused of fraud, forgery or coining (Table $4 \mathrm{~b}$ ). Only 1.7 percent of the accused were indicted for coining, but 14 percent of Jewish accused were coiners while the Irish were also three times more likely than average to be accused of uttering or making false coin - all these figures giving some credence to Colquhoun's observations in 1795 that "German and Dutch Jews live chiefly by... the sale of stolen goods... The lower ranks among the Irish, and the German Jews, are the chief supporters of the trade of circulating base money in London; - there is said to be scarce an Irish labourer who does not exchange his week's wages for base money... The Jews principally confine themselves to the circulation of copper; while the Irish women are the chief utterers of base silver." ${ }^{83}$ By contrast the relatively small numbers of black offenders that were prosecuted very rarely drew the attention of contemporary commentators, but the black accused clearly followed their own particular patterns of offending. They were very rarely involved in offences such as forgery or receiving, which required the perpetrator to be in possession of two assets that black people found it particularly difficult to obtain - literacy skills and the ownership of shop premises. Unsurprisingly, given that such a high proportion of them were servants, they were twice as likely to be accused of stealing in the dwelling house compared to the London-born.

It cannot, of course, be automatically assumed that these variations reflected real differences in the types and numbers of crimes committed by different ethnic groups. For example, the fact that contemporaries believed that the Irish were more violent and riotous, and that Jews were more willing to fence stolen goods, (or that both were notorious coiners) may have led them to be less willing to deal with such offenders informally. However, the massively higher recorded crime rates exhibited by the Irish compared to those of other groups raises many questions about the religious, ethnic, political and economic issues that may have either led certain groups to commit greater numbers of crimes, or made some Londoners more prejudiced against those groups and therefore more likely to prosecute them. It is remarkably difficult to find evidence about how late eighteenth-century Londoners felt about, and acted towards, different immigrant/ethnic groups, but one potential method of uncovering different levels of such prejudice is to look at the ways the criminal justice system treated different immigrant groups when they were accused of crimes at the Old Bailey. 
The Newgate Calendars are a much better source than the OBSP, not only because they systematically described the ethnicity of the accused, but also because they contain a much fuller list of them. The printers of the OBSP only had access to information about those who underwent a public trial at the Old Bailey, but the Calendars included an additional, and very substantial, group of offenders who avoided conviction because the cases against them were dismissed at two earlier, and essentially private, stages of the prosecution process. Between 1791 and 18055.0 percent of those who were due to be tried at the Old Bailey never even reached the grand jury hearing - usually because they were remanded, transferred or benefitted from their prosecutor failing to turn up or deliberately dropping the case. More importantly a further 16.6 percent of those listed for trial in the calendars had their indictments "not found" at the private grand jury hearing, because the gentlemen of that jury did not consider the prosecution case to be strong enough to justify a public trial. Since a further 27.1 percent of the accused were found not guilty by the petty jury after a full public trial, a remarkably large proportion of those listed in the Calendars - almost exactly half - avoided conviction in one way or another.

The overall impact of the decisions made at these various pre-conviction stages on offenders from different ethnic/national groups can be seen in Table $5 .{ }^{84}$

Since this tabulation brings together the verdicts arising from all types of offence, it may be slightly distorted by the fact that different offences sometimes have different overall verdict patterns. However, since variations in the mix of offences that different immigrant groups were accused of were relatively minor (Table 4) this is unlikely to have distorted the findings significantly. Since most specific offences, such as robbery or receiving, involve relatively small numbers from each particular immigrant group this overall sample is probably the best available guide to jury attitudes. However, given that around half of the accused in every group were charged with simple larceny (i.e. plain stealing with no aggravating circumstances) the pattern for all offences can be checked out for possible distortions by tabulating plain stealing cases alone, and this has therefore been done in Table 6.

Table 5 - Verdict by Place of Birth, All Old Bailey Accused 1791-1805

\begin{tabular}{|c|c|c|c|c|c|c|c|}
\hline \multirow[b]{2}{*}{ PLACE OF BIRTH } & \multicolumn{7}{|l|}{ VERDICT } \\
\hline & $\begin{array}{l}\text { remains } \\
\text { no trial }\end{array}$ & $\begin{array}{l}\text { NotFound } \\
\text { or disch'd }\end{array}$ & $\begin{array}{l}\text { Not } \\
\text { Guilty }\end{array}$ & Guilty & $\begin{array}{l}\text { Unknown } \\
\text { Verdict }\end{array}$ & $\begin{array}{l}\text { All } \\
\text { Verdicts }\end{array}$ & $\begin{array}{l}\text { Sample } \\
\text { Size }\end{array}$ \\
\hline Average all Places & 5,0 & 16,6 & 27,1 & 50,7 & 0,5 & 100 & 11927 \\
\hline London & 3,3 & 18,3 & 26,7 & 51,6 & 0,2 & 100 & 4544 \\
\hline Rest of England & 6,5 & 15,5 & 26,8 & 50,6 & 0,6 & 100 & 4819 \\
\hline Scotland & 5,2 & 18,6 & 24,5 & 50,9 & 0,7 & 100 & 269 \\
\hline Ireland & 3,4 & 17,5 & 27,7 & 50,9 & 0,5 & 100 & 1188 \\
\hline
\end{tabular}




\begin{tabular}{|l|l|l|l|l|l|l|l|}
\hline Wales & 2,6 & 13,2 & 24,3 & 59,3 & 0,5 & 100 & 189 \\
\hline Germany & 3,0 & 13,9 & 28,7 & 54,5 & 0,0 & 100 & 101 \\
\hline Rest of Europe & 4,1 & 16,5 & 29,8 & 47,9 & 1,7 & 100 & 121 \\
\hline Restof the World & 7,0 & 22,3 & 16,6 & 54,1 & 0,0 & 100 & 157 \\
\hline Black & 8,9 & 26,7 & 20,0 & 44,4 & 0,0 & 100,0 & 45 \\
\hline unknown & 9,8 & 10,2 & 37,3 & 39,1 & 3,5 & 100 & 539 \\
\hline
\end{tabular}

Note partial verdict added to guilty ; insane added to guilty

The figures on all offences seen in Table 5 suggest that verdict patterns varied remarkably little between the main immigrant groups. The percentage of the accused found guilty, which averaged 50.7 in the whole sample of 11,927 cases was almost identical to the figure of 50.9 found for those born in Ireland, in Scotland and in Europe (if Germany is included in one overall European figure). Since the percentages for the London born (51.6) and for those born in the rest of England (50.6) were also very near to the average, there is no evidence here of any significant bias against any of these groups. Almost inevitably there was slightly more variation in conviction rates amongst the smaller subgroups of immigrants where sample sizes were between 101 and 189 accused. offenders born in the rest of the world were between 3 and 4 percent more likely to be convicted, but although nearly a third of these non-European offenders were black, this did not mean that black offenders received above average conviction rates. On the contrary, the proportion of the black accused that were found guilty was well below average at 44.4 percent. The main reasons for this were that a much higher proportion of black offenders avoided even coming before the grand jury (8.9 percent compared to 5.0 for other accused), and that the black accused were also much more likely to have their indictment "not found" by that jury (26.7 percent compared to 16.6 for other groups). This highly favourable treatment in the early stages meant that although only 20 percent of black offenders were then acquitted by the petty jury compared to an average of 27.1 percent, overall the black accused were still less likely to be convicted than their white equivalents ${ }^{85}$. The only major immigrant group that received seriously worse treatment than the accused as a whole were, rather surprisingly, the Welsh, who had an overall conviction rate of 59.3 percent. (Table 5) The Welsh accused were not only the least likely to avoid going to jury trial - mainly because the grand jury dismissed fewer of the accusations against them than they did for any other migrant group - but also had an acquittal rate that was well below average.

Table 6 - Plain Stealing, Old Bailey Accused 1791-1805 ; Verdict by Place of Birth. Percentages

\begin{tabular}{|l|l|l|l|l|l|l|l|}
\hline \multicolumn{2}{|l|}{ VERDICT } \\
\hline PLACE & $\begin{array}{l}\text { Remains } \\
\text { no trial }\end{array}$ & $\begin{array}{l}\text { NotFound } \\
\text { or disch'd }\end{array}$ & $\begin{array}{l}\text { Not } \\
\text { Guilty }\end{array}$ & Guilty & $\begin{array}{l}\text { Unknown } \\
\text { Verdict }\end{array}$ & $\begin{array}{l}\text { All } \\
\text { Verdicts }\end{array}$ & Sample \\
\hline Average all Places & 2,5 & 23,5 & 27,5 & 46,4 & 0,1 & 100 & 6246 \\
\hline
\end{tabular}




\begin{tabular}{|l|l|l|l|l|l|l|l|}
\hline London & 1,5 & 27,0 & 25,8 & 45,7 & 0,0 & 100 & 2407 \\
\hline Rest of England & 3,7 & 20,4 & 27,8 & 47,9 & 0,2 & 100 & 2626 \\
\hline Scotland & 2,1 & 27,7 & 27,0 & 43,3 & 0,0 & 100 & 141 \\
\hline Ireland & 1,2 & 24,0 & 28,8 & 46,0 & 0,0 & 100 & 587 \\
\hline Wales & 0,0 & 20,0 & 24,8 & 55,2 & 0,0 & 100 & 105 \\
\hline Germany & 5,9 & 17,6 & 33,3 & 43,1 & 0,0 & 100 & 51 \\
\hline Rest of Europe & 1,6 & 23,0 & 31,1 & 44,3 & 0,0 & 100 & 61 \\
\hline Rest of the World & 4,7 & 31,4 & 16,3 & 47,7 & 0,0 & 100 & 86 \\
\hline Unknown & 2,2 & 15,9 & 47,3 & 34,6 & 0,0 & 100 & 182 \\
\hline
\end{tabular}

If we analyse plain larceny accusations only (Table 6), the pattern remains much the same. Once again, despite the much smaller sample sizes in plain larceny cases, the conviction rates of the London-born, those from the rest of England, and from Ireland deviated very little from the average (around 1 percent). The main groups with below average conviction rates were the Scots and the Europeans (about 3 percent) and the only group with much higher conviction rates were the Welsh, who were once again nearly 9 percent more likely to be found guilty ${ }^{86}$. (Table 6) Since sample sizes in the case of the Welsh are relatively small (189 for all offences and 105 for simple larceny only) it is difficult to draw firm conclusions, but these figures suggest that further research is needed on attitudes towards the Welsh in late eighteenth-century England. London had a sizable Welsh community by this period, but unlike most migrant groups it was dispersed very broadly across the metropolis. ${ }^{87}$ Most historians have argued that the Welsh were relatively well integrated and accepted ${ }^{88}$ and there is very little evidence in the London newspapers of any consciously voiced discrimination against them. The contemporary broadsheet poem that began "Taffy was a Welshman, Taffy was a thief" ${ }^{89}$ may reflect an underlying attitude that could have helped to create an assumption that a Welshman accused of theft was likely to be guilty, but there is no way of gauging whether this was true. These figures suggest, however, either that the London jurors were rather less sympathetic towards the Welsh than we have been led to expect, or that, for some reason, the evidence against a higher proportion of Welshmen and women was particularly strong.

Even more surprising perhaps than the apparently harsh treatment given to the Welsh, was the failure of the London juries to convict above average numbers of Irish offenders. As the author has discussed elsewhere ${ }^{90}$, attitudes to the Irish almost certainly changed for the worse in the early nineteenth century, but Tables 5 and 6 , covering the period 1791 to 1805 , offer little evidence that Irish offenders were treated any more harshly than other groups. It is particularly interesting that the Irish and Scottish accused received such similar treatment given that contemporary opinion was so much more positive about the Scots that it was about the Irish. In 1815, for example, one regular visitor of the London poor compared these two groups of migrants as follows. "North Briton throws off 
its swarms no less numerous perhaps than those of the sister kingdom [Ireland] : and London may be reckoned the general rendezvous of both ; but they proceed thither with very different views ; the one to save money the other to spend what they get in jollity. The Scotch are industrious, frugal, persevering and provident... the Irish on the contrary are lazy, extravagant, thoughtless... and possessed of... much ingenuity." ${ }^{11}$ Another common theme in contemporary discourse - the more 'violent' character of the Irish ${ }^{92}$ even appeared in discussions of their attitudes as workers. In 1825 the European Review, in contrasting the "Character of the English, the Scots and the Irish" in this context commented that "the poor Englishman takes his toil as lightly as he can and counts the days till... Sunday, The poor Scotsman chaffers about the amount of his wages and hoards it with great parsimony... The poor Irishman drudges hard for little; and seeks his pleasure in warm protestations of friendship - demonstrated perhaps by the cudgel. When young his glory is his brawl." ${ }^{\text {93 }}$ It is interesting to note therefore, that although the Irish received the same overall conviction rate as other groups, (Tables 5 and 6 ) there was one type of case in which there is evidence that the old Bailey jurors were prejudiced against the Irish - those involving charges of interpersonal violence.

Violent offences were relatively rarely tried at the old Bailey. Murder and rape prosecution rates were low and the vast majority of accusations of non-lethal violence were heard in the lower courts, where research on the Victorian period has shown that the Irish were vastly over-represented. This meant that less 4 percent of the cases listed in the Newgate Calendars fell into this category. However, while the results need to be treated with caution, given the relatively small numbers involved, the verdicts returned against those charged with violent offences indicate that one ethnic group, the Irish, were considerably more likely to be found guilty (Table 7). On average 42 percent of all those accused of violence were convicted. The Irish figure was 52 percent. Any Irishmen facing an indictment for violence was considerably more likely to be found guilty, especially if he was accused of rape, when he was three times more likely to be convicted. ${ }^{94}$ Thus although the vast majority of old Bailey verdicts do not appear to show any evidence of discrimination against particular migrant groups, there were exceptions - as there also were when it came to sentencing the 50 percent of the sample who had failed to avoid conviction.

Table 7 - Violent Offences, Old Bailey Accused 1791-1805. Verdict by Place of Birth. Percentages

\begin{tabular}{|c|c|c|c|c|c|c|c|}
\hline & VERDICT & & & & & & \\
\hline PLACE & $\begin{array}{l}\text { Remains } \\
\text { no trial }\end{array}$ & $\begin{array}{l}\text { NotFound } \\
\text { or disch'd }\end{array}$ & $\begin{array}{l}\text { Not } \\
\text { Guilty }\end{array}$ & Guilty & Unknown & total \% & Sample \\
\hline Average all Places & 11,4 & 20,3 & 24,4 & 42,4 & 1,1 & 100 & 439 \\
\hline London & 9,1 & 18,9 & 23,5 & 47,7 & 0,8 & 100 & 132 \\
\hline Rest of England & 16,6 & 17,2 & 24,5 & 39,7 & 2 & 100 & 151 \\
\hline Scotland & 7,7 & 30,8 & 15,4 & 46,2 & 0 & 100 & 13 \\
\hline Ireland & 4,7 & 26,7 & 16,3 & 52,3 & 0 & 100 & 86 \\
\hline
\end{tabular}




\begin{tabular}{|l|l|l|l|l|l|l|l|}
\hline Rest of Europe & 33,3 & 33,3 & 33,3 & 0 & 0 & 100 & 6 \\
\hline Rest of the World & 33,3 & 33,3 & 0 & 33,3 & 0 & 100 & 6 \\
\hline Wales & 12,5 & 12,5 & 50 & 25 & 0 & 100 & 8 \\
\hline Germany & 0 & 50 & 0 & 50 & 0 & 100 & 2 \\
\hline Unknown & 8,6 & 14,3 & 48,6 & 25,7 & 2,9 & 100 & 35 \\
\hline
\end{tabular}

\section{V}

Given the smaller sample sizes involved, the conclusions that can be drawn from Table 8, which analyses the sentencing policies pursued by the Old Bailey judges towards different migrant groups, are inevitably more tentative. This is especially the case in relation to Black and Jewish offenders (sample sizes 27 and 23) and they have therefore been excluded from this Table. Neither of these groups appear to have received either very harsh or very unusual patterns of punishment, and since figures based on such small samples require very careful handling and have already been discussed in detail elsewhere, sentencing policies towards Black and Jewish offenders are not analysed here. ${ }^{95}$ Of the 6,009 offenders convicted at the Old Bailey between 1791and 1805, 41.1 percent were sentenced to imprisonment, 36.4 percent were transported, 13.8 percent capitally convicted and 5.0 percent were whipped. Use of the latter two punishments varied relatively little between the main migrant groups in Table 8 . There were some minor differences. Those from outside the United Kingdom where slightly more likely to be whipped and although capital conviction rates for Scottish and Irish convicts were almost exactly the same as for all the accused, for the Welsh they were lower and for non-United Kingdom residents they were somewhat higher.

Table 8 - Percentage Given Each Sentence by Place of Birth, All Old Bailey Accused 1791-1805

\begin{tabular}{|l|l|l|l|l|l|l|l|l|l|l|}
\hline & \multicolumn{2}{|l|}{ PLACE } & All & London & $\begin{array}{l}\text { Rest } \\
\text { of } \\
\text { Eng. }\end{array}$ & Scotland & Ireland & Wales & Germany & $\begin{array}{l}\text { Rest } \\
\text { of } \\
\text { Eur. }\end{array}$ \\
\hline $\begin{array}{l}\text { Rest } \\
\text { of } \\
\text { World }\end{array}$ & Unknown \\
\hline $\begin{array}{l}\text { Fined, bound } \\
\text { over, burnt in } \\
\text { hand }\end{array}$ & 2,1 & 2,1 & 2,2 & 1,5 & 1,2 & 1,8 & 1,9 & 1,8 & 0,0 & 4,8 \\
\hline $\begin{array}{l}\text { Whipped or } \\
\text { Pilloried only }\end{array}$ & 5,0 & 5,2 & 5,0 & 4,4 & 4,3 & 2,7 & 1,9 & 10,5 & 8,2 & 5,3 \\
\hline Imprisoned & 41,1 & 35,1 & 42,9 & 54,4 & 51,7 & 55,9 & 35,2 & 31,6 & 29,4 & 50,7 \\
\hline Transported & 36,4 & 40,1 & 35,7 & 25,7 & 28,0 & 32,4 & 40,7 & 35,1 & 47,1 & 32,5 \\
\hline
\end{tabular}




\begin{tabular}{|c|c|c|c|c|c|c|c|c|c|c|}
\hline $\begin{array}{l}\text { Put into } \\
\text { Armed Forces }\end{array}$ & 1,5 & 1,8 & 1,3 & 0,7 & 1,3 & 0,0 & 3,7 & 1,8 & 1,2 & 1,4 \\
\hline $\begin{array}{l}\text { Sentenced to } \\
\text { Death* }\end{array}$ & 13,8 & 15,8 & 12,9 & 13,2 & 13,5 & 7,2 & 16,7 & 19,3 & 14,1 & 5,3 \\
\hline Total & 100 & 100 & 100 & 100 & 100 & 100 & 100 & 100 & 100 & 100 \\
\hline Sample size & 6009 & 2330 & 2426 & 136 & 601 & 111 & 54 & 57 & 85 & 209 \\
\hline $\begin{array}{l}\% \quad \text { Death } \\
\text { Respited }\end{array}$ & 81,3 & 85,0 & 78,0 & 66,7 & 82,7 & 87,5 & 88,9 & 72,7 & 83,3 & 63,6 \\
\hline $\begin{array}{l}\% \text { Death } \\
\text { Hanged }\end{array}$ & 18,7 & 15,0 & 22,0 & 33,3 & 17,3 & 12,5 & 11,1 & 27,3 & 16,7 & 36,4 \\
\hline $\begin{array}{l}\text { Total } \\
\text { Sentenced to } \\
\text { Death }\end{array}$ & 100 & 100 & 100 & 100 & 100 & 100 & 100 & 100 & 100 & 100 \\
\hline
\end{tabular}

* Excluding sentence unknown \& those not convicted

By contrast, the use of transportation and imprisonment, the two main punishments which between them were given to more than three quarters of convicted offenders, varied very considerably. Rather surprisingly, the data on the transportation or imprisonment decision, which was the main point at which the judges had considerable discretion, suggests that the main immigrant groups were treated relatively leniently. Given that the average imprisonment term was considerably less than a year compared to a minimum transportation term of seven years, most convicted offenders would almost certainly have regarded prison as the more lenient punishment. It is therefore very interesting that sentencing policies towards the Irish, the Welsh and the Scots all showed a similar tendency to favour imprisonment over transportation by a ratio of nearly 2 to 1 . The London-born, by contrast, were more likely to be transported than imprisoned, as were the small group of black convicts. This apparent leniency towards Welsh, Scottish and Irish offenders is difficult to explain, but it may have been mainly a function of the sentencing policies pursued towards the London-born. The latter were much more likely to be in their later teens - an age group often considered particularly good material for transportation. Alternatively, this sentencing preference may have been influenced by contemporary rhetoric about the need to get young London-born offenders away from their long-standing criminal connections, or by the sense that, since most migrant offenders had already lost contact with their homelands and families, they would be less affected by transportation and more likely to welcome it.

The sentencing patterns for those accused of plain stealing alone was very similar to that for all offences, with the Welsh again being given particularly lenient treatment, as they were nearly twice as likely to be imprisoned rather than transported. Thus sentencing patterns did not necessarily replicate the differences observed at the verdict stage, for if this had been the case the Welsh would have been singled out for heavier punishment. The sentencing patterns for violent offences did, however, duplicate fairly precisely the 
biases seen at earlier stages in the trial process. Once again the Irish were much more severely dealt with. Only a third of murderers were sentenced to death, the majority being found guilty of the lesser charge of manslaughter and then imprisoned. By contrast, two thirds of Irish murder convicts were hanged..$^{96}$

VI

If we return to the case-study with which this article began, it therefore becomes clear that the two methodologies pursued in this article both complement each other in vital ways, and suggest rather different conclusions. On its own our detailed reconstruction of the 1799 Cock and Hen Club case (and to a lesser extent of the similar case that happened in 1797) might lead us to conclude that the criminal justice system and its main officials police, magistrates and judges - had a serious tendency to discriminate against migrant minorities. However, any temptation to generalise from this micro-history clearly runs into major difficulties. When they were tried at the Old Bailey, the vast majority of migrants were not discriminated against in any visible way by either the jurors or the judges. Indeed, ethnic groups sometimes received more favourable treatment enabling them, for example, to avoid transportation more often than the native born. Paradoxically, however, the 1799 Cock and Hen Club trial was in some ways typical of a broader pattern of very real discrimination. The broader group of cases which the Newgate Calendars enable us to study between 1791 and 1805 (which ironically do not include the 1799 Cock and Hen Club case because this is one of the years for which the Calendars are missing) indicate that the policies uncovered in our micro-history were not in many ways untypical. In the relatively small group of cases involving accusations of violence, the Old Bailey did inflict harsher verdicts and sentences on the Irish accused, and contemporary perceptions that the Irish were more prone to violence were almost certainly one of the core reasons why this was the case. Moreover, the massive overrepresentation of the Irish amongst the accused (Table 1) is difficult to explain without some reference to the possibility that major subgroups of the London population harboured major prejudices towards the Irish.

Thus while the statistics that can be extracted from the Newgate Calendars about the treatment of different immigrant/ethnic groups at the Old Bailey suggest that this level of the criminal justice system was rarely systematically biased against such groupings, this is not the whole story. Both the qualitative and the quantitative work presented here indicate that in certain contexts, and in relation to certain types of crime, specific ethnic groups might be seriously discriminated against. The treatment meted out to migrants accused of crime at the Old Bailey reflected the complex and ambivalent attitudes of the London population, and of those who manned the capital's policing networks and courts, towards the various ethnic/national groups they found in their midst. To understand both the justice and the injustices meted out by the eighteenth and early nineteenthcentury criminal justice system historians have to use both micro-studies and quantitative sources, for both the shadows and the light that each casts on the other are indispensable. 


\section{BIBLIOGRAPHY}

\section{REFERENCES}

Anon, 'Mendicity', Quarterly Review, 1815, 14, p. 122-3.

Beattie, J., Crime and the Courts in England 1660-1800, Oxford, Oxford University Press, 1986.

Beattie, J., Policing and Punishment in London 1660-1750 : Urban Crime and the Limits of Terror, Oxford, Oxford University Press, 2001.

Beattie, J., The First English Detectives ; The Bow Street Runners and the Policing of London 1750-1840, Oxford, Oxford University Press, 2012.

Chater, K., Untold Stories: Black People in England and Wales during the Period of the British Slave Trade, 1660-1807, Manchester, Manchester University Press, 2009.

Clark, P., 'The Multi-Centred Metropolis : The Social and Cultural Landscapes of London 1600-1840' in Clark, P., and Gillespie, R. (Eds), Two Capitals : London and Dublin 1500-1840, Oxford, Oxford University Press, 2001.

Colquhoun, P., A Treatise on the Police of the Metropolis, London, C. Dilly [5 $5^{\text {th }}$ Edition], 1797.

Conley, C., 'Wars Among Savages : Homicide and Ethnicity in the Victorian United Kingdom', Journal of British Studies, 2005, 44, p. 775-95.

Cookson, J., The British Armed Nation 1793-1815, Oxford, Oxford University Press, 1997.

Dickinson, H., 'The Irish Rebellion of 1798 : History and Memory', in Broich, U., Dickinson, H., Hellmuth, E., Schmidt, M., (Eds), Reactions to Revolutions : The 1790s and their Aftermath, Berlin, LitVerlag, 2007.

Emsley, C., 'An Aspect of Pitt's “Terror” : Prosecutions for Sedition during the 1790s', Social History, 1981, 6, p. 155-84.

Emsley, C., 'Repression, “Terror" and the Rule of Law in England During the Decade of the French Revolution', English Historical Review, 1985, 100, p. 801-29.

Emsley, C., The English Police : A Political and Social History, [2 ${ }^{\text {nd }}$ Edition], Harlow, Longman, 1996. Endelman, T., The Jews of Georgian England 1714-1830, Ann Arbor, University of Michigan Press, 1999.

Endelman, T., The Jews of Britain 1656 to 2000, Berkeley, University of California Press, 2002. Fenske, H., 'International Migration : Germany in the 18th Century', Central European History, $1980,13$.

George, M.G., London Life in the Eighteenth Century, Harmondsworth, Penguin Books, 1985.

Gray, D., and King, P., 'The Killing of Constable Linnell : The Impact of Xenophobia and of Elite Connections on Eighteenth-Century Justice', Family and Community History, 2013, 16.

Godfrey, B., Lawrence, P., and Williams, C., History and Crime, London, Sage Publications, 2008. 
Hay, D., 'Property, Authority and the Criminal Law', in Hay, D., Linebaugh, P., Rule, J., Thompson, E.P., and Winslow, C. (Eds), Albion's Fatal Tree ; Crime and Society in Eighteenth-Century England, Harmondsworth, Penguin, 1975.

Harris, A., Policing the City : Crime and Legal Authority in London 1780-1840, Columbus, Ohio State University Press, 2004.

Hitchcock, T., Down and Out in Eighteenth-Century London, London, Bloomsbury, 2004.

Jones, E., 'The Welsh in London in the Seventeenth and Eighteenth Centuries', The Welsh Historical Review, 1981, 10, p. ?461-79.

Jones, E., The Welsh in London 1500-2000, Cardiff, University of Wales Press, 2001.

Kellenbenz, H., 'German Immigrants in England', in Holmes, C., (Ed) Immigrants and Minorities in British Society, London, George Allen and Unwin, 1978, p. 63-80.

King, P., Crime and Law in England 1750-1840: Remaking Justice from the Margins, Cambridge, Cambridge University Press, 2006.

King, P., 'Ethnicity, Crime and Justice : The Treatment of the Irish at the Old Bailey, 1750-1825', Journal of British Studies, 2013, p. ?390-414.

King, P. and Carter Wood, J., 'Black People and the Criminal Justice System : Prejudice and Practice in Later Eighteenth- and Early Nineteenth-Century London', Historical Research, 2015, 88, p. $100-124$.

Lees, L.H., Exiles of Erin ; Irish Migrants in Victorian London, Manchester, Manchester University Press, 1979.

MacFarlane, K., Minority Justice : Ethnic Minorities and Criminal Justice in Eighteenth-Century London, PhD Thesis, University of Toronto, 2008.

Myers, N., Reconstructing the Black Past. Blacks in Britain 1780-1830, London, Frank Cass, 1996.

Paley, R., The Middlesex Justices Act of 1792 : Its Origins and Effect. PhD Thesis, Reading University, 1983

Paley, R., 'An Imperfect, Inadequate and Wretched System ? Policing London before Peel', Criminal Justice History, 1989, 10, p. 95-130.

Panayi, P., 'The German Poor and Working Classes in Victorian and Edwardian London', in Alderman, G., and Holmes, C., (Eds) Outsiders and Outcasts, London, Duckworth,1993, p. 53-70.

Reynolds, E., Before the Bobbies : The Night Watch and Police Reform in Metropolitan London 1720-1830, Stanford, Stanford University Press, 1998.

Richardson, R., Death, Dissection and the Destitute, London, Routledge and Kegan Paul, 1987.

Rude, G., Hanoverian London 1714-1808, Berkeley, University of California Press, 1971.

Shannon, H., 'Migration and the Growth of London 1841-91 : A Statistical Note', Economic History Review, 1935, 5, p. ?81-3.

Ward, R., Print Culture, Crime and Justice in Eighteenth-Century London, London, Bloomsbury, 2014.

White, J., A Great and Monstrous Thing ; London in the Eighteenth Century, London, Bodley Head, 2012. 


\section{NOTES}

1. This article comes out an ESRC-funded project on 'Ethnicity, Crime and Justice in England 1700-1825' (Number RES-000-22-2696). The author would like to thank John Carter Wood, research fellow, and Bridget Lewis, research assistant, for their many labours and comments. This work was first given as a paper at the workshop on 'Polices et ordre public en France et en Angleterre (1750-1850). Les perspectives de l'historiographie contemporaine', April 2014, at the Institut d'études avancées de Paris. Peter King is Emeritus Professor of History at Leicester University, England. His publications include Crime, Justice and Discretion in England 1740-1820 (Oxford, 2000), Crime and Law in England 1750-1840 (Cambridge, 2006) and 30 journal articles and book chapters on the history of crime, justice and welfare in eighteenth- and nineteenth-century Britain including 'Exploring and Explaining the Geography of Homicide: Patterns of Lethal Violence in Britain and Europe 1805-1900', Revue Européenne d'histoire/ European Review of History, 2013,20 , p. ?967-88. He is currently working on a monograph on post-execution punishment and the criminal corpse in England 1700-1834.

2. For an overview of historical work on ethnicity, crime and justice that makes this clear, see Godfrey, Lawrence \& Williams (2008, p. ?101-26).

3. Endelman (1999, p. ?192-225) ; Endelman (2002, p. ?41-79) ; Myers (1996, p. ?82-103); Chater (2009, p. ?102-35).

4. The Old Bailey Sessions Papers are available online at [http://www.oldbaileyonline.org] (henceforth shortened to OBSP). The Newgate Calendars are in The National Archives of the UK (henceforth TNA) HO 26 1-11. They cover Oct 1791 to Dec 1805, but records for Oct 1795 to Sept 1796 and Oct 1798 to Sept 1800 are missing and for Dec 1794 to Sept 1795 do not contain ethnic information. These periods are excluded from this analysis.

5. George (1985, p. ?120-32) : Clark (2001, p. ?251-2) ; Hitchcock (2004, p. ?6-8).

6. King (2013, p. ?390-414); King and Wood (2015, ?p. ?100-24).

7. Endelman (1999, p. ?192-225) ; Endelman (2002, p. ?41-79); Myers (1996, p. ?82-103) ; Chater (2009, p. ?102-35) ; King (2013, p. ?390-414) ; King and Wood (2015, ?p. ?100-24).

8. Weekly Register, 15 May 1799.

9. Rude (1971, p. ?113) ; White (2012, p. ?157).

10. OBSP report of the Trial of Timothy Brian et all in May 1799 which is henceforth referred to by its reference number on http://www.oldbaileyomline.org which is t17990508-21.

11. t17990508-21; Star, 11 May 1799.

12. In other reports spelt Hearn : t17990508-21 ; London Packet or New Lloyd's Evening Post, 11 February 1799.

13. t17990508-21; The Times, 11 May 1799.

14. E. Johnson's British Gazette and Sunday Monitor, 12 May 1799 ; Whitehall Evening Post, 9 May 1799 ; Evening Mail, 10 May 1799 ; Morning Chronicle, 11 May 1799 ; The Times, 11 May 1799 ; Lloyd's Evening Post, 11 May 1799.

15. t17990508-21.

16. t17990508-21.

17. Morning Chronicle, 11 May 1799; The Times, 11 May 1799; Whitehall Evening Post, 9 May 1799 ; t17990508-21. The reports specifically mentioned that Sassanacks/sasanaghs/sarseneg was the Irish word for English.

18. The reports on the coroner's hearing suggest he died on 22 January, Oracle and Daily Advertiser, 26 January 1799 ; True Briton, 26 January 1799. 
19. Sun, 23 January 1799 ; General Evening Post, 22 January 1799 ; True Briton, 23 January 1799. For the tendency of the London press to present the Irish in stereotyped ways that were not usually positive, see King (2013, p. ?390-414).

20. Patrick Holland, for example, was reported to have received a severe wound to the face; St James Chronicle or British Evening Post, 28 February 1799.

21. London Chronicle, 24 January 1799.

22. Arrest reports ; Oracle and Daily Advertiser, 14 February 1799 ; London Chronicle, 12 February 1799 ; Lloyd's Evening Post, 13 February 1799 ; Sun,14 February 1799 ; Bell's Weekly Messenger, 17 February 1799 ; Craftsman or Say's Weekly Journal, 16 February 1799 ; St James Chronicle or British Evening Post, 28 February 1799 ; Morning Chronicle, 1 March 1799.

23. Whitehall Evening Post, 30 March 1799 ; Evening Mail, 1 April 1799 ; Morning Chronicle, 2 April 1799 ; Morning Post and Gazetteer, 2 April 1799.

24. The Times, 11 May 1799.

25. Evening Mail, 10 May 1799 ; Lloyd's Evening Post, 10 May 1799.

26. $\mathrm{t} 17990508-21$.

27. t17990508-21 ; Oracle and Daily Advertiser, 11 May 1799 ; Star, 11 May 1799.

28. Evening Mail, 10 May 1799.

29. The judge admitted 'there might, in strictness, be some objections to the warrant't17990508-21.

30. Oracle and Daily Advertiser, 11 May 1799.

31. Star, 6 April 1799 ; Evening Mail, 5 April 1799 ; London Packet or New Lloyd's Evening Post, 5 April 1799.

32. $\mathrm{t} 17990508-21$.

33. Hay (1975).

34. $\mathrm{t} 17990508-21$.

35. $\mathrm{t} 17990508-21$.

36. $\mathrm{t} 17990508-21$.

37. $\mathrm{t} 17990508-21$.

38. t17990508-21; Evening Mail, 11 May 1799.

39. True Briton, 11 May 1799.

40. Beattie, (1986, pp. 525-30) ; Ward, (2014, pp. 157-203) ; Richardson (1987).

41. Craftsman or Say's Weekly Journal, 18 May 1799.

42. True Briton, 14 May 1799.

43. Star, 14 May 1799.

44. Craftsman or Say's Weekly Journal, 18 May 1799.

45. Paley (1989); Reynolds (1998); Beattie (2001); Harris (2004).

46. Beattie (2012).

47. Paley (1983).

48. Observer, 21 October 1798 reported that in 1797 the Bow Street office was given well over 30 percent of the funding made available to the eight police offices.

49. Beattie (2012); Reynolds (1998).

50. Emsley (1996, p. ?20) ; Emsley (1985, p. ?820) briefly mentions that the new police offices gave the government a new executive arm in London after 1792 but does not offer any further analysis.

51. Emsley (1981), Emsley (1985, p. ?812-23).

52. Emsley (1981, p. ?15) ; True Briton, 22 January 1798.

53. General Evening Post, 3 March 1789 ; Evening Mail, 9 April 1792. Bullock hunting was a regular feature of the capital. Young men took a bullock from Smithfield and chased it through the streets.

54. Morning Herald, 6 March 1789. 
55. London Chronicle, 3 March 1789.

56. Diary or Woodfall's Register, 10 April 1792 ; Evening Mail, 9 April 1792.

57. General Evening Post, 3 March 1789.

58. London Chronicle, 23 May 1797 ; St James's Chronicle or British Evening Post, 23 May 1797 ; Times, 24 May 1797 ; Star,25 May 1797 ; True Briton, 25 May 1797 ; Evening Mail, 22 May 1797.

59. Public Ledger, 24 May 1797. The Defenders were a secret Roman Catholic society who by 1796 had allied with the United Irishmen and who joined with them in the Irish Rebellion of 1798.

60. Bell's Weekly Messenger, 28 May 1797 ; Times, 24 May 1797 ; Public Ledger, 24 May 1797.

61. Public Ledger, 24 May 1797.

62. Bell's Weekly Messenger, 28 May 1797 ; Oracle and Public Advertiser, 24 May 1797.

63. Oracle and Public Advertiser, 24 May 1797.

64. Bell's Weekly Messenger, 28 May 1797.

65. Dickinson (2007, p. ?33-6).

66. Emsley (1985, p. ? 816).

67. Gray and King (2013).

68. TNA HO 26/1-11.

69. Colquhoun (1797, p. ?xi.)

70. TNA HO 26/1-11. Seven offenders were simply described as 'born at sea.'

71. Fenske (1980) ; Panayi (1993, p. ?54) ; Kellenbenz (1978, p. ?75).

72. Colquhoun (1797, P. ?xi.) ; World, 14 April 1790.

73. Shannon (1935, p. ?81-30).

74. Jones (2001, p. ?55) ; Jones (1981, p. ?463).

75. King (2013, p. ?400).

76. Kellenbenz (1978, p. ?75) estimates 4-5,000 German born Londoners in the mid-eighteenth century.

77. King and Wood (2015, p. ?111).

78. Endelman (1999, p. ?172-4).

79. Endelman (1999).

80. Myers (1996).

81. Cookson (1997, p. ?126-7) ; George (1985, p. ?120) ; and Lees, (1979, p. ?92-3) ; Endelman, (1999) ; Panayi (1993) ; Jones (2001, p. ?55-99). The occupations of female offenders were rarely recorded. Irish and Welsh offenders were 3 or 4 percent more likely to be women than the London-born, but the only groups that contained much smaller proportions of women than the average (which was 27 percent) were those born outside Great Britain.

82. Jones (1981, p. ?473) ; Jones (2001, ?p. ?100-25).

83. Colquhoun (1797, p. ?120 \& 189-90).

84. To create large enough samples to enable the impact of place of birth on the Old Bailey verdicts to be calculated, nationalities have only been used when a sample of at least 100 accused came from that country.

85. For a full discussion see King and Wood (2015).

86. Since female offenders were considerably more likely to avoid conviction (King, 2006) one might expect the Welsh accused to include a less than average proportion of females but in fact they had a slightly higher proportion. Only the European accused had a much smaller than average proportion of women - 10 percent compared to an average of 26.5 percent.

87. Jones (2001, p. ?96-7) ; Jones (1981, p. ?464-6).

88. Conley (2005, p. ?781-2) ; Jones (2001, p. ?55).

89. Jones (1981, p. ?469).

90. King (2013, pp. 409-12).

91. Anon (1815, p. ?123).

92. Further discussion see King (2013, p. ?393-5). 
93. European Review article reprinted in the Observer 7 February 1825.

94. Further discussion, see King (2013).

95. King and Wood (2015, p. ?119-24).Using surnames as a surrogate for ethnic description, a technique which King and Wood rejected as too problematic, Karen Macfarlane has concluded that in seven of the nine years she sampled between 1770 and 1786 Jewish conviction rates were well above average. The question therefore remains open. Contemporary prejudices were certainly reinforced during the period she uses by the murder in 1771 of a servant during a late night burglary by a Jewish gang in Chelsea, after which something of a moral panic developed. MacFarlane (2008, p. 211-5).

96. Since the author has recently published a detailed analysis of attitudes to the Irish in the London courts during this period - King (2013) - their treatment will not be discussed in detail here.

\section{ABSTRACTS}

Research on English courts in the late nineteenth and twentieth centuries has indicated the vital role that ethnicity and migrant status played in determining the ways the accused were treated. This article examines the experiences of immigrant communities in dealing with police and the courts during the late eighteenth and early nineteenth-century London. The criminal justice system and its main officials - police, magistrates and judges - had a serious tendency to discriminate against migrant minorities. Yet the treatment of different ethnic groups at the old Bailey suggests that the criminal justice system was rarely systematically biased against immigrants. So, although the Irish were overrepresented amongst defendants at London courts and often given harsher verdicts and sentences at the Old Bailey, other ethnic groups, such as the Welsh, were sometimes treated more favourably. The treatment meted out to migrants accused of crime at the old Bailey reflected the complex and ambivalent attitudes of the London population. The micro-history case studies examined also show that any attempt to generalise runs into major difficulties. To understand both the justice and the injustices meted out by the eighteenth and early nineteenth-century criminal justice system historians have to use both micro-studies and quantitative sources, for both the shadows and the light that each casts on the other are indispensable.

La recherche sur les tribunaux anglais de la fin du dix-neuvième et du vingtième siècle a montré le rôle décisif de l'ethnicité et du statut de migrant dans la manière dont l'accusé était traité. Cet article étudie l'expérience des groupes migrants dans leurs rapports avec la police et les tribunaux inférieurs vers la fin du dix-huitième et le début du dix-neuvième siècle à Londres. Le système pénal et ses principaux agents - police, magistratures - avait une forte tendance à discriminer les minorités migrantes. Toutefois, le traitement des différents groupes ethniques au tribunal d'old Bailey suggère que les biais envers les migrants étaient rarement systématiques. Ainsi, bien que les Irlandais fussent surreprésentés parmi les accusés dans les tribunaux londoniens et souvent plus sévèrement condamnés à l'old Bailey, d'autres groupes ethniques, tels que les Gallois, étaient parfois traités avec plus d'indulgence. Le traitement infligé aux migrants accusés de crimes à l'old Bailey reflétait la complexité et l'ambivalence des attitudes de la population londonienne. Cette analyse micro-historique montre aussi que tout essai de généralisation se heurte à des difficultés majeures. Pour comprendre à la fois la justice et les 
injustices infligées par le système pénal de cette époque, les historiens doivent utiliser aussi bien les études micro-historiques que les sources quantitatives, car les ombres et la lumière que ces sources projettent l'une sur l'autre sont toutes également indispensables.

\section{AUTHOR}

\section{PETER KING}

Professor Emeritus, University of Leicester - pk180@le.ac.uk 